\title{
PERAN PONDOK PESANTREN (PONPES) MODERN DALAM PEMBERDAYAAN EKONOMI MASYARAKAT
}

\section{THE ROLE OF ISLAMIC BOARDING SCHOOL MODERN IN ECONOMIC EMPOWERMENT OF SOCIETY}

\author{
A Sugandi'ia, HB Tanjung1, dan RK Rusli ${ }^{1}$ \\ 1 Program Studi Manajemen Pendidikan Islam, Fakultas Keguruan dan Ilmu Pendidikan, \\ Universitas Djuanda Bogor, Jl. Tol Ciawi No. 1 Kotak Pos 35 Ciawi Bogor 16720 \\ a Korespondensi: Asep Sugandi, Email: asepsugandi100@gmail.com \\ (Diterima: 10-08-2017; Ditelaah: 11-08-2017; Disetujui: 16-09-2017)
}

\begin{abstract}
Pondok pesantren in its development consistent as social role and institution of Islamic education. Social roles in community empowerment in an effort to promote, motivate, and strengthen various aspects of life. The study is intended to describe the role of pesantren in the economic empowerment of society, supporting factors and inhibiting factors. The research was undertaken at Pesantren Modern Ummul Quro Al-Islami Leuwiliang Bogor. The research method used is a qualitative method of case study. Technique of collecting data through interview and observation. Primary data source is the leadership of pesantren, while secondary data are documentation, and observation. The final result of this research shows that there is community empowerment by Pesantren Modern Ummul Quro Al-Islami. Form of empowerment in the form of social, economic, and educational fields. Based on the literature review of the concept of community economic empowerment states that empowerment aims to give power or strength, so that people, groups, or communities become independent.
\end{abstract}

Keywords: boarding school, economic, empowerment, society.

\begin{abstract}
ABSTRAK
Pondok pesantren dalam perkembangannya konsisten sebagai peran sosial dan lembaga pendidikan Islam. Peran sosial pada pemberdayaan masyarakat dalam upaya mendorong, memberikan motivasi, dan penguatan berbagai aspek kehidupan. Penelitian bertujuan untuk mendeskripsikan peran pesantren dalam pemberdayaan ekonomi masyarakat, faktor pendukung dan faktor penghambat. Penelitian dilaksanakan di Pesantren Modern Ummul Quro Al-Islami Leuwiliang Bogor. Metode penelitian yang digunakan adalah metode kualitatif studi kasus. Teknik pengambilan data melalui wawancara dan pengamatan. Sumber data primer adalah pimpinan pesantren, sedangkan data sekunder berupa dokumentasi, dan pengamatan. Hasil akhir penelitian ini menunjukkan ada pemberdayaan masyarakat oleh Pesantren Modern Ummul Quro Al-Islami. Bentuk pemberdayaan berupa bidang sosial, ekonomi, dan bidang pendidikan. Berdasarkan kajian pustaka mengenai konsep pemberdayaan ekonomi masyarakat menyatakan bahwa pemberdayaan bertujuan memberi daya atau kekuatan, sehingga orang, kelompok, atau masyarakat menjadi mandiri. Kata kunci: ekonomi, masyarakat, pemberdayaan, pesantren modern.
\end{abstract}

Sugandi A, HB Tanjung, dan RK Rusli. 2017. Peran pondok pesantren (ponpes) modern dalam pemberdayaan ekonomi masyarakat. Tadbir Muwahhid 1(2): 99-115. 


\section{PENDAHULUAN}

Kualitas peningkatan diri manusia ialah bagian yang menjadi sumber daya untuk pembangunan merupakan menjadi prasyarat yang utama dalam memperbaiki kesejahteraan rakyat. Tujuan utama ialah membangunan MDGs (Millenium Development Goals) di Indonesia, memprioritaskan penanganan pada kemiskinan merupakan tekad dalam kebijakan pemerintah yang harus adanya dukungan dari instansi atau institusi pembangunan. Agar upaya tersebut berhasil secara baik dan perlu didampingi secara pengembangan dan gerakan pemberdayaan bagi masyarakat kemudian dapat dilaksanakan secara intensif (Suyono dan Haryanto 2009).

Gerakan pemberdayaan untuk masyarakat didukung dengan program pendidikan yang dijalankan pemerintah, yaitu pendidikan karakter. Pendidikan karakter tidak dipungkiri berupa pendidikan yang melaksanakan secara terus-menerus selama 24 jam yang memberikan contoh atau bentuk pendidikan dari berbagai aspek. Aspek itu meliputi ilmu pengetahuan, keterampilan/praktik, serta ketauladanan (role model). Ketiga aspek pendidikan dapat dijalankan dengan pola pendidikan berasrama. Pola pendidikan seperti itu di Indonesia telah ada yaitu pola pendidikan di pondok pesantren. Pendidikan pondok pesantren merupakan pendidikan yang asli dan tergolong tua di Indonesia. Eksistensinya dapat dipertahankan, sehingga sanggup bertahan dari perkembangan ilmu pengetahuan, budaya, sosial hingga sekarang walaupun diterpa oleh berbagai dinamika zaman. Ciri khas yang sering ditonjolkan pada pesantren atau lembaga pendidikan lainnya adalah adanya sistem pada pendidikan 24 jam, dengan mengkondisikan santri di lokasi asrama bertujuan mempermudah untuk mengaplikasikan sistem pendidikan dengan tujuan lebih totalitas (Siradj 2014).

Pondok pesantren mengikuti perkembangan yang sanggup mengikuti perubahan zaman, bahkan menjadi agen perubahan bagi perkembangan masyarakat. Masyarakat (community) adalah sekumpulan/kelompok orang yang mempunyai kesamaan dalam bahasa yang secara bersama-sama, yang dapat mereka rasakan, termasuk yang berada dalam kelompok-kelompok itu, ataupun yang memiliki bahasa yang sama.

Masyarakat Leuwiliang Kabupaten Bogor, khususnya di desa Leuwimekar berdasarkan sensus ekonomi tahun 2015 terdapat keluarga penerima Kartu Jaminan Sosial (KJS) berjumlah 315 kepala keluarga. Sementara yang termasuk kategori warga miskin berjumlah 1350 orang dari jumlah penduduk desa Leuwimekar sebanyak 3873 orang berdasarkan data tahun 2015 .

Berdasarkan data tersebut, tingkat ekonomi masyarakat Leuwimekar harus adanya peningkatan untuk bisa mencapai kesejahteraan. Keterbatasan anggaran pemerintah, perlu ada peran dari kelompok masyarakat untuk membantu dan bersinergi dengan pemerintah. Kelompok tersebut diantaranya pondok pesantren.

Di Banyusuci tepatnya desa Leuwimekar, terdapat sebuah pondok pesantren (ponpes) Modern Ummul Quro Al-Islami. Pesantren tersebut dibilang cukup maju dan mendapat dukungan masyarakat sekitar. Konstribusi terhadap warga sekitar dapat dirasakan manfaatnya. Melihat kemajuan lembaga yang cukup membanggakan, pesantren ini berperan menggerakkan dan memajukan ekonomi masyarakat sekitar khususnya dan Kecamatan Leuwiliang pada umumnya. Dengan begitu, pesantren telah 
berperan penting pada program pemberdayaan ekonomi dalam masyarakat.

Program pemberdayaan ekonomi bagi masyarakat salah satu program yang diyakini dapat meningkatkan kesejahteraan. Di tengah tugas pokoknya pada pendidikan, pesantren bertanggung jawab secara sosial terhadap masyarakat sekitarnya. Bersamaan dengan peran, pesantren memiliki fungsi, yaitu:

mentransformasikan ilmu agama Islam dan nilai-nilai ke-Islaman (Islamic Values); (2) menjadi lembaga bidang keagamaan yang selalu melaksanakan kontrol sosial (social control); dan (3) melakukan perbaikan rekayasa dibidang sosial (social engineering).

Melalui fungsinya, ponpes (pondok pesantren) dapat menjadi pendorong, memberikan motivasi, dan melakukan penguatan agar membantu masyarakat mampu mandiri. Seperti aspek pendidikan, budaya, agama, sosial, dan aspek ekonomi. Seiring perkembangan ilmu dan teknologi, perkembangan sosial budaya, dan tuntutan lapangan pekerjaan, maka peran pesantren juga mengalami perkembangan.

Seiring dengan kemajuan sosial, budaya, ekonomi, politik dan ilmu pengetahuan, peran pondok pesantren pun mengalami kemajuan. Eksistensi lembaga pondok pesantren akan tergerus oleh lembagalembaga lain yang bukan pondok pesantren dan mampu menghasilkan beragam sumber daya manusia (SDM) yang berkualitas. Kebutuhan akan SDM sebagai produk lembaga pendidikan tidak terkecuali pondok pesantren, akan menentukan eksistensi lembaga tersebut. Masyarakat akan percaya terhadap lembaga pendidikan yang mampu menghasilkan atau memproduksi sumber daya manusia (SDM) yang berkualitas serta berbobot. Pondok pesantren yang mengakar di tengah-tengah masyarakat, keberadaannya sangat penting dalam peningkatan sumber daya manusia. Fungsi pondok pesantren jadi lebih strategis dimana pemerintah masih memiliki keterbatasan pada bidang pemberdayaan masyarakat.

Sejalan dengan uraian diatas, pondok pesantren seharusnya terlibat secara aktif pada mobilisasi pembangunan masyarakat desa, masyarakat kota, atau dimana pondok pesantren itu berada. Komunitas ataupun kelompok pondok pesantren terbiasa melaksanakan kegiatan pembangunan bagi kesejahteraan masyarakat. Hubungan yang harmonis antara santri dan masyarakat, antara kiyai dan kepala desa. Pesantren tempat pembinaan moral-spiritual, ilmu agama Islam, dan ilmu-ilmu umum.

Interaksi sosial-budaya antara masyarakat sekitar dan pesantren harus terlihat dalam kegiatan sosial, hal pendidikan, keagamaan dan perekonomian. Pondok pesantren sesuai fungsinya, harus selalu progresif melihat kemajuan perkembangan disegala bidang. Perubahan kedalam harus senantiasa dilakukan untuk menghadapi permasalahan sosial kemasyarakatan.

Produk pesantren atau lulusannya sanggup bersaing secara sehat dengan beragam lulusan pendidikan non pesantren. Untuk mentransformasikan pondok pesantren telah melaksanakan pemberdayaan masyarakat, diperlukan langkah-langkah khusus dalam menghasilkan santri-santri sebagai agent of change terhadap arus modernisasi, sosialbudaya, dan ekonomi. Pesantren merupakan tempat maupun sarana pengembangan potensi pemberdayaan masyarakat.

Fokus penelitian dimaksudkan agar penelitian dapat dilakukan secara mendalam pada bidang-bidang spesifik. Pada penelitian ini fokus yang diambil 
adalah bidang pemberdayaan ekonomi. Untuk membatasi permasalahan penelitian, maka penelitian ini difokuskan pada peran serta pesantren dalam pemberdayaan ekonomi.

\section{MATERI DAN METODE}

\section{Materi}

Menurut Latif (1993), pondok pesantren sebagai lembaga sosial, memiliki satu keunikan yang sangat berbeda dan tidak dimiliki oleh lembaga lain. Pondok pesantren mempunyai kesempatan dan kemungkinan besar untuk dapat berkiprah dan berperan pada penguatan masyarakat. Pondok pesantren menjadi pelopor perubahan (agent of change) di tengahtengah masyarakat baik sosial, ekonomi, dan budaya.

Kemajuan ilmu pengetahuan dan teknologi, serta dinamika kemajuan masyarakat yang dinamis pada era terakhir ini, menghadirkan harapan baru dari sektor pendidikan yang menyediakan banyak pilihan. Keragaman tuntutan pendidikan pada waktunya akan menimbulkan orientasi dan peran pesantren menjadi beragam pula, yang secara sosiologis mengantarkan pada pengkategorian tipologi pesantren.

Adapun variasi bentuk atau model sebuah pesantren yang berkembang sekarang ini secara umum dapat dikelompokan pada tiga macan tipe pesantren, yaitu: (1) pesantren modern (khalafiyah); (2) pesantren tradisional (salafiyah); dan (3) pesantren khusus (takhasus). Untuk membedakan ketiga tipe tersebut dilihat dari ciri-cirinya, yaitu:

\section{a. Pesantren Modern (Khalafiyah)}

Ciri utama pesantren modern adalah kepemimpinan cenderung korporatif, program pendidikan agama dan pendidikan umum. Para santri tinggal di asrama atau dalam pondok. Pemaduan antara pola pembelajaran asli pesantren dengan sistem madrasah atau sistem sekolah, memiliki kurikulum yang jelas atau penggabungan antara kurikulum pesantren dengan kurikulum Kementrian Agama atau Kementrian Pendidikan.

Sarana dan prasarana pendidikan disediakan secara khusus, seperti asrama, ruang belajar, masjid, dan lain-lain. Pembagian dan pengorganisasian kerja dibuat dengan mempertimbangkan kompetensinya.

\section{b. Pesantren Tradisional (Salafiyah)}

Pesantren salafiyah hampir merupakan antagonis dari pondok pesantren modern. Kepemimpinan bersifat perorangan, berpusat pada seorang kiyai. Pembagian kerja tidak spesifik (khusus), kalaupun ada sifatnya sebagai pembantu kiyai saja. Materi pengajaran berfokus pada pengetahuan agama Islam atau sering dipakai dengan istilah kitab kuning. Pondok pesantren menjadi rumah tinggal para santri, pengajaran menurut keinginan kiyai dengan metode sorogan, bandongan, dan lainnya yang merupakan asli metode milik pesantren.

Sulaiman (2010) menguraikan karakteristik pesantren salafiyah antara lain: (1) sistem pengelolaan pendidikan cenderung kiyai sebagai pemimpin sentral, sekaligus pemilik pesantren; (2) hanya mengajarkan pengetahuan agama (islam); (3) materi pendidikan bersumber dari kitab-kitab berbahasa arab klasik atau biaya disebut kitab kuning; (4) menggunakan sistem pendidikan tradisional dan sorogan; (5) hubungan antara kiyai, ustadz, dan santri bersifat hirarkis; (6) keseharian santri cenderung bersifat komunal dan egaliter. 


\section{c. Pondok Pesantren Khusus (takhasus)}

Type pondok pesantren ini memiliki ciriciri asrama hanya jadi tempat tinggal santri, sementara belajar di luar pesantren. Proses pembelajaran malam hari atau siang hari (sering disebut santri kalong). Kurikulum tidak terprogram dengan jelas. Ciri-ciri lainnya berupa pengkhususan pada keterampilan tertentu, misalnya pertanian dan peternakan.

Sementara pemerintah melalui Kementrian Agama, Dirjen Kemenag tahun 2003 menggolongkan tipologi pondok pesantren menjadi empat tipe, yaitu tipe A, B, C, dan D. Uraian diatas untuk memberikan batasan atau pemahaman ada model dan bentuk pesantren saat ini. Namun demikian model dan bentuk pondok pesantren tidak hanya yang telah disebutkan di atas.

\section{d. Pemberdayaan Masyarakat}

Pemberdayaan masyarakat dapat diartikan sebagai usaha pemberian daya (Menurut kamus bahasa Indonesia), memberikan kemampuan untuk melakukan sesuatu atau kemampuan bertindak. Pemberdayaan yang berasal dari kata daya berarti juga kekuatan, tenaga atau yang menyebabkan sesuatu bergerak. Pemberdayaan berarti juga merupakan sebuah proses, cara, dan perbuatan untuk menjadi berdaya.

Berangkat dari arti dan makna pemberdayaan yang telah diuraikan di atas, dapat disimpulkan bahwa pemberdayaan adalah sebuah proses transfer daya, kekuatan, tenaga, dan kekuasaan dari satu pihak yang berdaya kepada orang, kelompok orang atau masyarakat agar memiliki kemampuan untuk mampu bergerak sendiri dalam mencapai kesejahteraan hidupnya. Pemberdayaan menunjuk suatu orang, masyarakat, dan kelompok lainnya dapat berpatisipasi, berbagi pengontrolan atas, dan memengaruhi terhadap kejadian-kejadian dan pihak lain yang dapat mempengaruhi kehidupannya.

Damsir (2016) menyebutkan bahwa masyarakat diartikan sebagai satu kesatuan hidup orang yang bersosialisasi dengan kebiasaan yang sama secara terus-menerus pada suatu rasa identitas bersama. Berdasarkan makna kamus dan berbagai pendapat ahli tersebut, maka pemberdayaan masyarakat dimaknai suatu proses transfer power (daya atau kuasa) pada yang lemah atau mengembalikan power kepada pemiliknya semula, melalui proses tersebut orang, kelompok, atau masyarakat mampu mengelola kebutuhan dan permasalahannya sendiri.

Pemberdayaan masyarakat (empowering comunity) adalah suatu proses transfer daya, tenaga, atau kekuatan dari pihak yang berdaya kepada kelompok masyarakat agar mampu mengelola kehidupannya secara mandiri dalam mencapai kesejahteraan baik lahir maupun batin. Pemberdayaan masyarakat dilakukan dengan mempertimbangkan kondisi sosial-ekonomi masyarakat itu sendiri. Pemberdayaan masyarakat desa tentu tidak akan sama dengan masyarakat kota. Maka perlu dianalisis terlebih dahulu sebelum melakukan proses pemberdayaan.

Pemberdayaan terhadap masyarakat harus memposisikan masyarakat bukan hanya sebagai obyek tetapi harus mampu menjadi subyek. Banyak pendapat para ahli tentang bagaimana proses pemberdayaan dilakukan. Secara filosofis, pemberdayaan berarti penyuluhan, sehingga harus ada tenaga penyuluh. Artinya pemberdayaan tidak dapat dilakukan hanya satu kali, tetapi harus berulang-ulang sampai obyek yang diberdayakan sanggup mandiri. Posisi 
masyarakat bukanlah obyek penerima manfaat (beneficiaries) yang tergantung pada pemberian pihak luar seperti pemerintah, melainkan dalam posisi sebagai subyek (agen atau partisipan yang bertindak) yang berbuat secara mandiri. Berbuat secara mandiri bukan berarti lepas dari tanggung jawab negara.

Pemerintah sebagai pihak yang memiliki tanggung jawab utama dalam hal pemberdayaan masyarakat, telah menyatakan yang tercantum pada Permendagri RI Nomor: 7 tahun 2007 tentang Kader Pemberdayaan Masyarakat. Pada intinya pemerintah menyatakan bahwa pemberdayaan merupakan upaya membangun masyarakat dalam rangka mewujudkan kemampuan dan kemandirian dalam kehidupan bermasyarakat, berbangsa dan bernegara.

Pemberdayaan pada akhirnya tidak boleh memberikan ketergatungan, tetapi harus sanggup mendorong kreativitas dan kemandirian masyarakat. Sanggup berswakarsa, swadaya, dan swadana dalam mencapai tujuan kesejahteraan ekonomi bersama dalam masyarakat.

\section{Sejarah Singkat Pesantren}

\section{Kondisi khusus}

Pembangunan Pondok Pesantren Ummul Quro Al-Islami diawali dengan peletakan batu pertama oleh KH. Muhtar Royani sebagai pimpinan pesantren Riyadul Aliyah Bogor. Peletakan batu pertama pada tanggal 21 Juli 1993 yang bertepatan dengan tanggal 1 Muharram 1413 H. Sedangkan kegiatan pembelajaran baru dilaksanakan terhitung sejak tanggal 10 Juli 1994. Untuk memberi arah dan pedoman dalam rangka mewujudkan cita-cita pendiri disusun sebuah visi dan misi. Visi pesantren adalah terwujudnya generasi Islam yang unggul dalam prestasi, berakhlak mulia, beramal soleh dan tekun beribadah sesuai ajaran Islam ahlul sunah waljamaah. Sementara misi dituangkan dalam integrasi kurikulum yang memadukan ilmu agama dan ilmu umum (tanjiliyah dan kauniyah).

Legaliatas formal sebuah lembaga pendidikan sangat dibutuhkan sebagai upaya pengakuan dari pemerintah. Oleh sebab itu pendiri mendaftarkan keabsahan lembaga melalui pembentukan yayasan. Yayasan itu bernama Yayasan Pendidikan Ummul Quro al Islami yang berakta notaris Makbul Suhada, S.H., No:06/2014. Yayasan berfungsi sebagai payung hukum dalam mentaati aturan atau ketentuan pemerintah yang berkaitan dengan lembaga pendidikan formal.

Seiring dinamika masyarakat yang berkaitan dengan pendidikan, cenderung hasrat masyarakat sekarang dalam memilih tempat pendidikan bagi putra-putrinya cenderung menginginkan pendidikan yang lengkap. Artinya disamping belajar agama juga belajar ilmu umum berikut ijazahnya. Tentu saja ijazah yang berlaku secara nasional maupun internasional. Dengan kata lain ijazah formal terbitan Kemenag dan Kemendikbud menjadi tuntutan pada umumnya orang tua. Hal ini dapat dilihat bagi lembaga pendidikan yang hanya menyelenggarakan pengajaran agama saja, seperti pesantren salafiyah tidak terlalu banyak orang tua menitipkan putraputrinya jika dibandingkan lembaga pendidikan yang melaksanakan ujian persamaan negeri.

Berkaitan dengan uraian di atas, Pondok Pesantren Ummul Quro Al-Islami untuk menampung harapan masyarakat dengan menyelenggarakan kegiatan satuan pendidikan Madrasah Tsanawiyah (MTs) setingkat SMP dan Madrasah Aliyah (MA) setingkat SMA. Penyelenggaraan satuan pendidikan ini ditujukan untuk memberi 
kelengkapan sistem pendidikan ala pondok pesantren. Pondok pesantren menyadari bahwa tidak setiap santri itu dapat menjadi kiyai setelah menyelesaikan pendidikannya di pesantren. Bahkan walaupun seorang santri, ada yang bercita-cita melanjutkan pendidikannya ke jenjang pendidikan umum.

Guna menjawab tuntutan dan keinginan para orang tua yang menitipkan pendidikannya di pondok pesantren, maka pesantren berusaha meramu kurikulum yang dapat memuat ilmu-ilmu agama dan ilmu-ilmu umum. Pondok Pesantren Modern Ummul Quro Al-Islami berusaha menyusun kurikulum terpadu (integrated curriculum). Kurikulum terpadu dimaksud adalah perpaduan antara kurikulum pesantren modern, salafi, kemenag, dan kemendikbud. Kurikulum terpadu ini memuat lebih banyak mata ajar atau bidang studi jika dibandingkan dengan kurikulum negeri ataupun kurikulum khusus pesantren. Hal ini terjadi karena penggabungan materi ajar negeri dan pondok pesantren yang harus sama-sama diajarkan kepada santri. Sebagai konsekuensi logis dari banyaknya bidang studi adalah penambahan waktu belajar dan waktu penyelenggaraan evaluasi.

Masa pendidikan di Pondok Pesantren Ummul Quro Al-Islami pada dasarnya tidak terlalu berbeda dengan waktu pendidikan di MTs/SMP atau MA/SMA pada umumnya. Yang berbeda apabila ada santri yang masuk ke pesantren dari lulusan SMP/MTs. Mereka harus menempuh masa pendidikan selama empat tahun, atau istilah di pondok pesantren kelas intensif. Sementara bagi santri yang masuk berasal dari lulusan SD/MI harus menyelesaikan waktu pendidikan selama enam tahun. Selama enam tahun tersebut didalamnya telah menyelesaikan jenjang pendidikan SLTP dan SLTA.
Untuk mewujudkan visi dan misi pondok pesantren, pembangunan sarana dan prasarana pendidikan mutlak dibutuhkan. Oleh sebab itu secara bertahap melalui biro pembangunan dilaksanakan pembangunan sarana menurut skala prioritas dengan mempertimbangkan kemampuan biaya. Pada saat penelitian dilakukan, tercatat bahwa pesantren telah memiliki gedung asrama santri putra dan putri, masjid putra dan putri, kantor pelayanan santri dan wali santri, dan lapangan olahraga. Kantor, kantin, dan sarana administrasi keuangan atau bank. Sedangkan santri sebanyak 3451 putra dan putri. Jumlah tenaga pengajar sebanyak 215 orang, tenaga kependidikan 35 orang, dan karyawan sebanyak 78 orang. Sementara luas tanah telah mencapai kurang lebih sembilan hektar. Pada tahun 2018 direncanakan akan didirikan Perguruan Tinggi Ummul Quro. Pondok pesantren memandang bahwa untuk mengukur keberhasilan pendidikan pesantren adalah mengukur seberapa baik hasil lulusannya. Jika alumni mampu menjadi solusi di tengah masyarakat dengan pengabdiannya dalam segala bidang maka nama pesantren akan terbawa harum.

Kemajuan sebuah lembaga pendidikan salah satunya dipengaruhi oleh tempat dimana lembaga tersebut didirikan. Tempat yang strategis, mudah dijangkau, lingkungan yang kondusif, cuaca yang sejuk, dapat berkontribusi menjadi daya tarik masyarakat untuk berkunjung. Begitupula kondisi sosial-ekonomi masyarakat sekitar dapat mempengaruhi perkembangan lembaga pendidikan. Secara geografis letak Pondok Pesantren Modern Ummul Quro AlIslami terletak di Jl. Moh Noh Noer Rt.004/004 Leuwimekar Kecamatan Leuwiliang Kabupaten Bogor kode pos 16640. 
Berdasarkan uraian di atas, bahwa masyarakat disekitar lembaga pendidikan dapat berkontribusi baik positif maupun negatif. Pada umumnya kontribusi masyarakat sekitar selalu positif, begitu juga masyarakat yang berada disekitar Pondok Pesantren Ummul Quro Al-Islami. Masyarakat yang religius yang ditunjukkan oleh masyarakat Bogor disekitar pesantren.

Dari sudut kemampuan ekonomi atau mata pencaharian masyarakat sekitar pesantren adalah bertani. Masyarakatnya bermata pencaharian bertani, buruh bangunan, pedagang keliling, dan sebagaian kecil berdagang di pasar Leuwiliang Bogor. Dilihat dari keadaan ekonomi, mayoritas tergolong pada ekonomi lemah atau cenderung penduduk kurang mampu.

\section{Kondisi umum}

Lembaga pendidikan sedikit banyak akan dipengaruhi oleh keadaan lingkungan sekitarnya. Secara umum lingkungan terdiri dari lingkungan alamiah, berupa keadaan alam, misalnya alam pegunungan, pedesaan dan perkotaan. Berikutnya lingkungan sosial, berupa masyarakat yang berada disekitar lembaga pendidikan tersebut. Berbicara lingkungan masyarakat, dapat dilihat dari sisi sosial-ekonomi, budaya dan agama. Untuk membatasi lingkungan masyarakat agar tidak terlalu luas sebagai obyek penelitian, maka penelitian dilakukan di Desa Leuwimekar, RT 04 dan RW 04 dimana Pondok Pesantren Ummul Quro di dalammnya.

Berdasarkan keterangan dari kepala desa Leuwimekar jumlah penduduk setempat berjumlah 1850 jiwa. Berdasarkan pendidikan, masyarakat kampung Banyusuci rata-rata hanya selesai sekolah sampai tingkat SMP. Sedangkan menurut pekerjaaannya terdiri dari $50 \%$ petani dan buruh tani, $15 \%$ pedagang keliling baik yang di kampung sendiri ataupun yang di luar kampung, seperti di kota Bogor, Bekasi, Tangerang, dan Leuwiliang. Sementara $2 \%$ pedagang kecil di rumah atau buka kios-kios kecil di pasar Leuwiliang. Selebihnya ada yang menjadi pekerja bangunan, pekerja serabutan, menjadi sopir, dan karyawan.

Berdasarkan uraian diatas masyarakat sekitar pondok pesantren merupakan masyarakat pedesaan yang sudah tidak murni lagi sebagai masyarakat bertani. Tingkat pendidikan yang beragam, dengan rata-rata baru dapat menyelesaikan tingkat pendidikan pada jenjang pendidikan dasar sembilan tahun. Sementara tingkat sosialekonomi boleh dikatakan masih tergolong ekonomi lemah, setidak-tidaknya ada lima puluh persen yang belum memiliki pekerjaan dengan penghasilan tetap. Melihat kondisi masyarakat seperti ini, dilain pihak ada kelompok masyarakat yang cukup maju dan berkembang, misalnya pondok pesantren.

Untuk mendorong kemajuan masyarakat mencapai kesejahteraan hidup, perlu terlibat berbagai pihak. Pemerintah yang mempunyai kewajiban untuk mensejahterakan seluruh masyarakat, tidak cukup memiliki kemampuan, oleh sebab itu kelompok masyarakat yang perlu dilibatkan. Keterlibatan kelompok masyarakat dapat menyesuaikan dengan potensi dan kemampuan yang dimiliki. Peran lembaga pondok pesantren dapat membantu tugas dan tanggung jawab pemerintah.

Peran pemberdayaan dapat dilakukan oleh Pondok Pesantren Ummul Quro. Keberadaan lembaga pendidikan ini memiliki peran strategis dalam membantu mengembangkan baik di bidang ekonomi, pendidikan dan melakukan pemberdayaan masyarakat. 


\section{Metode}

Sugiyono (2016) menjelaskan bahwa metode penelitian menggunakan metode kualitatif dengan jenis penelitian studi kasus. Penelitian studi kasus adalah suatu proses pengumpulan data dan informasi secara mendalam, mendetail, intensif, holistic, dan sistematis tentang orang, kejadian, social setting (latar sosial), atau kelompok dengan menggunakan berbagai metode dan teknik serta banyak sumber informasi untuk memahami secara efektif bagaimana orang, kejadian, latar alami itu beroperasi atau berfungsi sesuai dengan konteksnya (Yusuf 2015).

Pada penelitian ini pendekatan yang digunakan adalah pendekatan kualitatif dengan jenis penelitian studi kasus. Studi kasus merupakan studi tentang kasus atau unit analisis tertentu. Dan menyatakan bahwa studi kasus merupakan cerita mengenai sesuatu yang unik, khusus, menarik, cerita tersebut dapat mengenai individu-individu, proses, programprogram, rukun tetangga, institusi-institusi, dan bahkan kejadian-kejadian (Arifin 2012). Tujuan studi kasus untuk memperoleh deskripsi yang utuh dan mendalam dari sebuah entitas. Data yang akan dideskripsikan pada penelitian ini yaitu peran pesantren dalam pemberdayaan ekonomi masyarakat.

Metode kualitatif peneliti dapat menjadi sumber utama dengan cara melakukan pengamatan dan ikut terlibat secara mendalam. Peneliti terlibat langsung terhadap obyek yang menjadi sumber pengambilan data. Penelitian yang mendalam diperlukan agar mampu menggali hal-hal yang sekecil-kecilnya tidak terlewatkan.

Sejarah Pondok Pesantren Seorang kiyai membangun sebuah pesantren, biasa diawali dari rumah milik sang kiyai. Selanjutnya seiring jumlah santri yang bertambah mulai membuat ruangan lainnya dengan kapasitas lebih besar yang memilki banyak fungsi sebagai sarana ibadah. Masjid merupakan bangunan vital yang harus dibangun sejak kiyai menerima murid untuk di didik. Sumber pengajaran biasanya digunakan kitab kuning. Diantara kitab tersebut diantaranya pendapat ulama penganut faham Syafi'i, merupakan satusatunya yang memberikan pengajaran secara formal dalam lingkungan pesantren. Tujuan utamanya ialah untuk mendidik dan menghasilakn calon-calon santri dan ulama.

Santri-santri yang bercita-cita menjadi ulama, dibekali dengan penguasaan bahasa Arab terlebih dahulu. Proses pembelajaran berbahasa Arab melalui seorang guru pembimbing atau disebut ustad dengan pola pengajaran sorogan. Pada saat ini kitabkitab yang masih diajarkan kepada santri dapat dikelompokkan kedalam delapan kelompok pengetahuan: (1) nahwu (syntak); (2) fiqh; (3) usul fiqh; (4) hadist; (5) tafsir; (6) tauhid; (7) tasawuf dan etika; dan (8) tarikh dan bahaghah.

Seorang alim akan dipanggil kiyai oleh masyarakat bila telah memiliki dan mendirikan pesantren dengan banyak anak santri serta memahami dan menguasai ilmu keagamaan yang mendalam. Tetapi gelar kiyai juga dapat diberikan sebagai gelar kehormatan, seperti pada benda-benda keramat.

Santri dibedakan menurut tradisi sebuah pesantren menjadi dua, yakni santri mukim dan santri kalong. Santri mukim berasal dari daerah yang domisilinya jauh sehingga harus menetap bersama kelompok lainnya di pesantren. Santri yang asalnya dari lingkungan sekitar pesantren sehingga tidak perlu menetap disebut "santri kalong". Untuk menjadi seorang kiyai, seseorang 
seharusnya berusaha dengan keras melalui jenjang yang bertahap. Pondok pesantren sangat erat hubungannya kehidupan masyarakat Islam Indonesia yang tak terpisahkan.

Pondok pesantren dikenal sejak lama, semenjak agama Islam datang di Nusantara. Sejarah pondok pesantren berkembang sejalan dengan perkembangan sosial budaya masyarakat Indonesia. Madrasah dan pesantren memiliki peran dalam memajukan serta mencerdaskan rakyat dan anak bangsa Indonesia besar sekali. Lembaga pendidikan bidang Islami yang menanamkan nilai Islam kepada diri para santri. Sebagai lembaga, pesantren memiliki ciri berbeda (khas) dibandingkan lembaga pendidikan (formal) lainnya.

Bila ditinjau berdasarkan pada sejarah pertumbuhannya, bagian-bagian didalamnya, pola kehidupan warganya, serta pola adopsi terhadap berbagai macam inovasi yang mengembangkan sistem pendidikan baik pada ranah konsep maupun praktik (Soebahar 2013). Bermacam-macam kegiatan dan aktivitas yang dilakukan pesantren di masyarakat, seperti bidang pendidikan, ekonomi, pertanian, peternakan, dan lain-lain.

Namun demikian ada kesamaan yang mendasar pada pondok pesantren, yaitu semuanya berorientasi pada kepentingan pengembangan agama kepada masyarakat. Pada awalnya kedudukan dan fungsi pondok pesantren hanya berfungsi sebagai alat penyebaran Islam. Namun seiring perkembangan zaman kegiatan pondok pesantren meliputi kegiatan kemasyarakatan dalam kehidupan seharihari.

Di zaman teknologi dan kemajuan hampir disemua bidang kehidupan, tidak bisa dihindari pesantrenpun ikut kedalam perubahan tersebut. Kebutuhan pekerja yang profesional menuntut lulusan pesantren sanggup bersaing agar terus eksis baik lembaga pesantren maupun alumninya. Kecenderungan masyarakat yang mengharapkan pendidikan di pesantren bukan hanya memahami ilmu-ilmu agama, juga pengetahuan umum.

Tuntutan masyarakat ini apabila tidak diantisipasi, akan mengurangi bahkan menghilangkan kepercayaan untuk menitipkan atau mensekolahkan putraputrinya masuk di pesantren. Adanya pondok pesantren menjadi penting sebagai tempat dan sarana mensosialisasikan rencana kegiatan pemerintah dan ujung tombak pembangunan ekonomi rakyat.

\section{HASIL DAN PEMBAHASAN}

\section{Hasil}

Berdasarkan hasil pengamatan dan wawancara dengan berbagai sumber, peneliti memperoleh data yang berhubungan dengan kegiatan pemberdayaan masyarakat oleh pondok pesantren meliputi lapangan pekerjaan, peluang berusaha atau berdagang, kegiatan sosial, dan pendidikan. Secara rinci dapat diuraikan sebagai berikut.

\section{Lapangan Pekerjaan}

Pondok pesantren yang tidak berhenti melakukan kegiatan pembangunan sarana, seperti gedung kelas dan gedung asrama membutuhkan tenaga kerja yang cukup banyak. Kebijakan pondok pesantren mengutamakan mencari tenaga kerja yang berada di sekitar pesantren. Apabila tidak ada, baru mencari pekerja dari tempat lain. Latar belakang kebijakan ini adalah agar pesantren membantu warga sekitar, menurut pak kiyai ini sudah termasuk pemberdayaan masyarakat. Masyarakat 
sekitar diberdayakan agar memperoleh penghasilan dalam memenuhi kebutuhan hidup sehari-hari. Pesantren harus memberi manfaat langsung kepada warga sekitar yang merupakan juga da'wah bilamal. Maka dalam menerima para pekerja tersebut dibuat persyaratan yang wajib dipatuhi, persyaratan itu adalah wajib shalat. Apabila diketahui melanggar persyaratan tersebut, maka langsung diberhentikan. Jenis lapangan pekerjaan yang tersedia sebagai berikut: (1) pekerja bangunan; (2) pekerja kebersihan; (3) pekerja cuci (laundry); (4) tukang masak; dan (5) petugas keamanan atau satpam. Sementara jenis pekerjaan tersebut yang bisa diserap. Bidang lapangan pekerjaan ini dirasakan sangat bermanfaat dan membantu penghasilan warga sekitar pesantren.

Tabel 1 Lapangan pekerjaan

\begin{tabular}{|c|c|c|c|c|}
\hline No. & $\begin{array}{c}\text { Jenis } \\
\text { Pekerjaan }\end{array}$ & Jumlah & \multicolumn{2}{|l|}{ Keterangan } \\
\hline 1. & $\begin{array}{l}\text { Pekerja } \\
\text { bangunan }\end{array}$ & $\begin{array}{l}25 \\
\text { orang }\end{array}$ & \multicolumn{2}{|c|}{ Semua laki-laki } \\
\hline 2. & $\begin{array}{l}\text { Tukang } \\
\text { cuci }\end{array}$ & $\begin{array}{l}47 \\
\text { orang }\end{array}$ & \multicolumn{2}{|l|}{$\begin{array}{l}\text { Semua } \\
\text { perempuan }\end{array}$} \\
\hline 3. & $\begin{array}{l}\text { Pekerja } \\
\text { kebersihan }\end{array}$ & $\begin{array}{l}15 \\
\text { orang }\end{array}$ & $\begin{array}{l}\text { Laki-laki } \\
\text { orang, } \\
\text { perempuan } \\
\text { orang }\end{array}$ & $\begin{array}{l}8 \\
7\end{array}$ \\
\hline 4. & Juru masak & $\begin{array}{l}17 \\
\text { orang }\end{array}$ & $\begin{array}{l}\text { Laki-laki } \\
\text { orang, } \\
\text { perempuan } \\
\text { orang }\end{array}$ & $\begin{array}{r}7 \\
10\end{array}$ \\
\hline 5. & Satpam & $\begin{array}{l}4 \\
\text { orang }\end{array}$ & $\begin{array}{l}\text { Laki-laki } \\
\text { orang, } \\
\text { perempuan } \\
\text { orang. }\end{array}$ & 2 \\
\hline & Jumlah & $\begin{array}{l}83 \\
\text { orang }\end{array}$ & & \\
\hline
\end{tabular}

Berdasarkan tabel 1, masyarakat telah dibantu melalui penyediaan lapangan pekerjaan oleh pesantren. Menurut keterangan kepala desa Leuwimekar, jumlah warga yang belum memilki pekerjaan tetap sekitar 335 orang (belum terdapat data pencari kerja/pengangguran yang pasti). Melalui penyediaan lapangan kerja oleh pondok pesantren, membantu pemerintah desa dalam mengurangi pengangguran.

Pesantren telah memberi manfaat kepada warga sekitar dan itu merupakan pemberdayaan masyarakat, menurutnya pemimpin pesantren sekaligus sebagai pendiri. Sementara konsep pemberdayaan dalam memberikan daya (kekuatan) kepada orang, kelompok, dan masyarakat sehingga orang, kelompok, dan masyarakat memiliki daya (kekuatan) secara mandiri untuk mencapai kesejahteraannya.

Apabila ditinjau dari azas manfaat, pesantren telah memberi manfaat terhadap warga, namun demikian konsep pemberdayaan belum sepenuhnya dikategorikan sebagai pemberdayaan masyarakat. Pemberdayaan mengharuskan orang yang diberdayakan tidak tergantung pada pihak lain, tetapi mampu mandiri dalam memenuhi kebutuhan hidupnya. Dengan demikian proses pemberdayaan perlu lebih dikembangkan dan ditingkatkan lagi. Ditinjau dari fungsi sosial, pesantren terhadap masyarakat. Sementara apabila manfaatnya, dimana masyarakat sekitar mempunyai pekerjaan dan penghasilan. Jadi pada kegiatan tersebut, pesantren baru menjalankan fungsi sosial.

\section{Bidang Ekonomi}

Sasaran pemberdayaan ekonomi adalah warga yang memiliki kegiatan home industry. Tujuannya memberi kesempatan untuk menjual hasil produksinya. 
Pemberdayaan bidang ekonomi bertujuan memberi penguatan kepada warga untuk menaikkan penghasilan. Untuk membantu meningkatkan penghasilan keluarga, warga sekitar pesantren diberi kesempatan berjualan dengan cara mengisi barang dagangan di koperasi pesantren.

Warga membuat barang dagangan berupa makanan seperti buras, pisang goreng, kue-kue, nasi uduk, dan lain-lain kemudian dititipkan di koperasi pesantren. Warga tidak menjual langsung karena dikhawatirkan akan mengganggu kegiatan disiplin santri, khususnya disiplin berbahasa. Barang dagangan warga dibayar secara penuh sesuai harga yang disepakati. Koperasi pesantren tidak memungut biaya apapun dalam menjual komoditi yang dititipkan oleh masyarakat. Dengan kegiatan ini, diharapkan dapat membantu penghasilan warga sekitar pondok pesantren.

\section{Bidang Sosial}

Bidang sosial yang dilaksanakan adalah memberikan santunan berupa beras kepada warga sekitar yang berstatus janda yang tidak mampu. Bantuan berupa beras diberikan setiap bulan. Jumlah yang diberikan sesuai kemampuan pesantren. Syarat penerima bantuan adalah mau shalat. Program ini mengandung maksud keberadaan pesantren sanggup memicu dan memacu kegiatan sosial. Disamping itu membuktikan bahwa pesantren dapat dirasakan manfaatnya oleh warga sekitar. Sebagai bentuk pemberdayaan bahwa pesantren bermanfaat untuk warga sekitar, dapat menjadi contoh untuk pihak lain. Jumlah penerima bantuan disesuaikan dengan kemampuan yang dimilki, yaitu untuk sementara 25 orang.

\section{Bidang Pendidikan}

Pada bidang pendidikan berupa menugaskan guru-guru tertentu untuk membina warga sekitar melalui pengajaran di mushola dan masjid. Seperti mengadakan ceramah, belajar baca tulis Al-qur'an, diskusi keagamaan dan melaksanakan shalat jum'at. Disamping itu, pesantren memberi bantuan kepada pengurus mushola dan masjid dalam bentuk dana kesejahteraan setiap bulan. Ada dua mushola dan satu masjid yang pengurusnya diberi bantuan. Pemberdayaan dibidang pendidikan tujuan utamanya untuk menetralisir atau setidaknya memberikan pencerahan kepada warga sekitar apabila muncul perbedaan-perbedaan pemahaman keagamaan di masyarakat.

Berdasarkan uraian di atas, peran pemberdayaan masyarakat yang telah dilakukan pada tabel 2 .

Tabel 2 Jenis pemberdayaan masyarakat

\begin{tabular}{|c|c|c|c|}
\hline No & $\begin{array}{c}\text { Jenis } \\
\text { Kegiatan }\end{array}$ & $\begin{array}{c}\text { Jumlah } \\
\text { Penerima }\end{array}$ & Keterangan \\
\hline 1. & $\begin{array}{l}\text { Penyediaan } \\
\text { Lapangan } \\
\text { pekerjaan }\end{array}$ & 79 orang & Fungsi sosial \\
\hline 2. & $\begin{array}{l}\text { Bantuan } \\
\text { beras setiap } \\
\text { bulan }\end{array}$ & 25 orang & Fungsi sosial \\
\hline 3. & $\begin{array}{l}\text { Berjualan di } \\
\text { koperasi } \\
\text { pesantren }\end{array}$ & 10 orang & $\begin{array}{l}\text { Pemberdayaan } \\
\text { masyarakat, } \\
\text { ada unsur } \\
\text { kreativitas dan } \\
\text { partisipasi }\end{array}$ \\
\hline 4. & $\begin{array}{l}\text { Menyediakan } \\
\text { guru atau } \\
\text { pengajar }\end{array}$ & 3 orang & Pendidikan \\
\hline
\end{tabular}


Berdasarkan Tabel 2, peran pesantren dapat dipastikan memberi manfaat kepada masyarakat sekitar. Masyarakat sekitar dapat memperoleh manfaat baik materil maupun non material.

\section{Proses Pemberdayaan}

Proses kegiatan pemberdayaan dilaksanakan dengan melibatkan tokoh masyarakat sekitar. Tokoh masyarakat dan tokoh agama ikut terlibat, seperti ketua RT dan ketua RW menjadi ujung tombak dalam pelaksanaan pemberdayaan. Pesantren meminta masukan dan usulan hal-hal apa saja yang sangat dibutuhkan oleh warga. Tentunya tidak semua usulan dapat dipenuhi, usulan tersebut dipilih dan dipilah menyesuaikan kemampuan pesantren.

Secara umum, usulan masyarakat berupa kebutuhan pekerjaan dan adanya warga yang secara fisik sudah tidak mampu lagi untuk bekerja, seperti para janda yang sudah lanjut usia. Dalam menjalankan program pemberdayaan masyarakat, atau lebih tepatnya pemberian bantuan, menetapkan sebuah syarat. Syarat yang ditentukan untuk memperoleh bantuan adalah kewajiban mengerjakan shalat lima waktu. Apabila dalam perkembangannya syarat tersebut dilanggar, maka program bantuan apapun akan dihentikan.

Berangkat dari hasil yang telah diuraikan di atas, proses pemberdayan belum tampak mengikuti sebagaimana yang ditentukan dalam ilmu manajemen. Prinsip manajemen mengajarkan adanya perencanaan yang baik, pelaksanan dan pengorganisasian, pengawasan dan evaluasi. Bagian yang harus dilengkapi adalah adanya bagian atau bidang yang menangani secara khusus dan profesional apabila program pemberdayaan masyarakat ingin berhasil.

\section{Faktor Pendukung dan Penghambat}

Pada setiap kegiatan pemberdayaan akan ditemukan faktor-faktor yang dapat mempercepat keberhasilan dan menghambat keberhasilan. Pada penelitian ini dapat ditemukan bahwa faktor pendukung untuk berjalannya proses pemberdayaan sebagai berikut.

a. Tersedianya sumber daya material yang cukup, sehingga mendukung programprogram yang akan dilaksanakan berjalan dengan cepat dan lancar.

b. Visi dan misi pondok pesantren yang menggariskan keberadaannya harus memberi manfaat khususnya kepada warga sekitar dan umat secara umum.

c. Pemimpin pesantren yang memberi dukungan penuh terhadap program pemberdayaan masyarakat.

d. Kondisi masyarakat yang kondusif dalam arti memberi dukungan penuh terhadap segala jenis kegiatan yang diprogramkan oleh pondok pesantren.

e. Terjalinnya komunikasi yang baik antara warga sekitar dan pengurus pesantren secara umum.

Menurut Depag (2001), hal-hal yang dapat menjadi penghambat dalam peran pondok pesantren dalam pemberdayaan masyarakat di antaranya adalah sebagai berikut.

a. Pengelolaan pemberdayaan belum menjadi divisi atau bidang tersendiri, sehingga belum adanya perencanaan yang baik.

b. Belum menjadi program prioritas, sehingga baru bersifat spontanitas dan kasuistik merespon masukan dan informasi warga sekitar.

c. Faktor sosial-ekonomi dan tingkat pendidikan masyarakat yang masih rendah mengakibatkan lambatnya 
memberi pemahaman terhadap pola pikir hidup mandiri.

d. Mental senang menerima dari pada memberi, menimbulkan sikap malas bekerja dan berusaha sungguh-sungguh. Kurang dedikasi memunculkan inovasi baru sebagai lahan usaha.

e. Keterbatasan peran pemerintah mensejahterakan warga masyarakat.

Berangkat dari adanya faktor-faktor dalam proses pemberdayaan, maka perlu diusahakan kerja sama antara pihak-pihak yang memangku kepentingan. Adanya sinergisitas antara pemerintah dan masyarakat termasuk didalamnya lembaga pendidikan seperti pondok pesantren. Keterlibatan pemerintahan dapat menjadi partner untuk meningkatkan berhasilnya program-program pemberdayaan oleh pondok pesantren.

\section{Pengaruh Pemberdayaan Terhadap Masyarakat}

Bagaimana dampak atau pengaruh dalam pemberdayaan apakah baik atau sebaliknya.

Tabel 3 Tanggapan masyarakat

\begin{tabular}{|c|c|c|c|}
\hline No. & $\begin{array}{c}\text { Bentuk } \\
\text { Pemberdayaan }\end{array}$ & Tanggapan & Keterangan \\
\hline 1. & $\begin{array}{l}\text { Penyediaan lapangan } \\
\text { kerja }\end{array}$ & $\begin{array}{l}\text { Sangat membantu dan } \\
\text { bermanfaat menambah } \\
\text { penghasilan warga }\end{array}$ & $\begin{array}{l}\text { Lima orang yang diwawancari } \\
\text { dari pekerja bangunan }\end{array}$ \\
\hline 2. & Bidang ekonomi & $\begin{array}{l}\text { Meningkatkan penghasilan } \\
\text { ibu rumah tangga }\end{array}$ & $\begin{array}{lrr}\text { Lima orang warga yang } \\
\text { menitipkan dagangan } \\
\text { koperasi pesantren }\end{array}$ \\
\hline 3. & $\begin{array}{l}\text { Pemberian santunan } \\
\text { berupa beras }\end{array}$ & $\begin{array}{l}\text { Sangat membantu } \\
\text { kebutuhan pokok }\end{array}$ & $\begin{array}{l}\text { Lima orang warga penerima } \\
\text { bantuan }\end{array}$ \\
\hline 4. & Bidang pendidikan & Sangat bermanfaat & $\begin{array}{l}\text { Dua penunggu masjid yang } \\
\text { diwawancara }\end{array}$ \\
\hline
\end{tabular}

Dari hasil wawancara yang dilakukan peneliti memperoleh tanggapan sangat baik, sebagaimana disajikan tanggapan masyarakat yang mendapat kegiatan pemberdayaan oleh pesantren.

Pemberdayaan bukan hanya dilakukan kepada masyarakat dilakukan tidak hanya kepada masyarakat di luar pondok pesantren. Tetapi kepada masyarakat di dalam pesantren itu pun dilakukan. Pemberdayaan internal lebih bertujuan memberikan kekuatan ekonomi kepada para santri diantaranya berupa tabungan masa depan dengan berbagai jenis. Tujuan utamanya memberikan jaminan kehidupan di masa depan kesejahteraannya.

Di antara program-program tersebut adalah pemberian saham kepada guru-guru atau santri yang memenuhi syarat. Menurut pimpinan pesantren, hal ini dimaksudkan untuk memberi jaminan kehidupan ekonomi dimasa depan kepada para guru dan karyawan yang telah mendedikasikan atau pengabdiannya. 


\section{Pembahasan}

Nama Ummul Quro diberikan oleh pendiri berasal dari bahasa Arab, Ummu dan Quro yang berarti ibunya desa. Maksudnya untuk tabarrokan dari kota suci Mekkah yang selalu menjadi perhatian masyarakat muslim dari seluruh dunia. Cita-cita dan harapan pendiri pesantren, pada saatnya nanti pesantren menjadi tempat pilihan masyarakat untuk datang berkunjung menuntut dan menimba ilmu pengetahuan. Nama tersebut juga merupakan do'a sang pendiri agar pesantren yang didirikannya menjadi besar, maju, dan ramai masyarakat datang untuk menjadi santri di pondok pesantren tersebut. Nama menurut pendiri harus memiliki makna do'a yang akan selalu diucapkan oleh setiap orang yang membaca, mengenal, mengunjungi tempat tersebut. Pendiri pesantren yakin, apabila sebuah nama menjadi do'a, maka usaha yang dilakukan dalam mewujudkan visi dan misi pesantren akan diberikan kemudahan untuk mencapainya. Hal ini dapat dilihat dengan perkembangan pesantren yang boleh dibilang cukup pesat menuju kemajuan dan perkembangan jumlah santrinya.

Pembangunan Pondok Pesantren Ummul Quro Al-Islami diawali dengan peletakan batu pertama oleh KH. Muhtar Royani sebagai pimpinan pesantren Riyadul Aliyah Bogor. Peletakan batu pertama pada tanggal 21 Juli 1993 yang bertepatan dengan tanggal 1 Muharram 1413 H. Sedangkan kegiatan pembelajaran baru dilaksanakan terhitung sejak tanggal 10 Juli 1994. Untuk memberi arah dan pedoman dalam rangka mewujudkan cita-cita pendiri disusun sebuah visi dan misi. Visi pesantren adalah terwujudnya generasi Islam yang unggul dalam prestasi, berakhlak mulia, beramal soleh dan tekun beribadah sesuai ajaran Islam ahlul sunah waljamaah. Sementara misi dituangkan dalam integrasi kurikulum yang memadukan ilmu agama dan ilmu umum (tanjiliyah dan kauniyah).

Legaliatas formal sebuah lembaga pendidikan sangat dibutuhkan sebagai upaya pengakuan dari pemerintah. Oleh sebab itu pendiri mendaftarkan keabsahan lembaga melalui pembentukan yayasan. Yayasan itu bernama Yayasan Pendidikan Ummul Quro al Islami yang berakta notaris Makbul Suhada,SH., No:06/2014. Yayasan berfungsi sebagai payung hukum dalam mentaati aturan atau ketentuan pemerintah yang berkaitan dengan lembaga pendidikan formal.

Seiring dinamika masyarakat yang berkaitan dengan pendidikan, cenderung hasrat masyarakat sekarang dalam memilih tempat pendidikan bagi putra-putrinya cenderung menginginkan pendidikan yang lengkap. Artinya disamping belajar agama juga belajar ilmu umum berikut ijazahnya. Tentu saja ijazah yang berlaku secara nasional maupun internasional. Dengan kata lain ijazah formal terbitan Kemenag dan Kemendikbud menjadi tuntutan pada umumnya orang tua. Hal ini dapat dilihat bagi lembaga pendidikan yang hanya menyelenggarakan pengajaran agama saja, seperti pesantren salafiyah tidak terlalu banyak orang tua menitipkan putraputrinya jika dibandingkan lembaga pendidikan yang melaksanakan ujian persamaan negeri.

Berkaitan dengan uraian di atas, Pondok Pesantren Ummul Quro Al-Islami untuk menampung harapan masyarakat dengan menyelenggarakan kegiatan satuan pendidikan Madrasah Tsanawiyah (MTs) setingkat SMP dan Madrasah Aliyah (MA) setingkat SMA. Penyelenggaraan satuan pendidikan ini ditujukan untuk memberi kelengkapan sistem pendidikan ala pondok pesantren. Pondok pesantren menyadari bahwa tidak setiap santri itu dapat menjadi 
kiyai setelah menyelesaikan pendidikannya di pesantren. Bahkan walaupun seorang santri, ada yang bercita-cita melanjutkan pendidikannya ke jenjang pendidikan umum.

Guna menjawab tuntutan dan keinginan para orang tua yang menitipkan pendidikannya di pondok pesantren, maka pesantren berusaha meramu kurikulum yang dapat memuat ilmu-ilmu agama dan ilmu-ilmu umum. Pondok Pesantren Modern Ummul Quro Al-Islami berusaha menyusun kurikulum terpadu (integrated curriculum). Kurikulum terpadu dimaksud adalah perpaduan antara kurikulum pesantren modern, salafi, kemenag, dan kemendikbud. Kurikulum terpadu ini memuat lebih banyak mata ajar atau bidang studi jika dibandingkan dengan kurikulum negeri ataupun kurikulum khusus pesantren. Hal ini terjadi karena penggabungan materi ajar negeri dan pondok pesantren yang harus sama-sama diajarkan kepada santri. Sebagai konsekuensi logis dari banyaknya bidang studi adalah penambahan waktu belajar dan waktu penyelenggaraan evaluasi

\section{KESIMPULAN DAN IMPLIKASI}

\section{Kesimpulan}

Berangkat dari hasil penelitian dapat diambil kesimpulan bahwa telah dilaksanakan program memberdayakan masyarakat yang telah melibatkan warga. Kegiatan pemberdayaan masyarakat tersebut yaitu: penyerapan tenaga kerja, pengembangan ekonomi masyarakat, kegiatan sosial, dan kegiatan pendidikan masyarakat. Pengaruh kegiatan tersebut memberikan penguatan terhadap ekonomi masyarakat sekitar pesantren.

Kegiatan santunan kepada beberapa orang (dua puluh lima orang) merupakan fungsi sosial pesantren terhadap masyarakat. Kegiatan tersebut menurut konsep pemberdayaan, tidak termasuk pada pemberdayaan. Walaupun demikian kegiatan tersebut sangat diperlukan warga sekitar pesantren. Jika dilihat dari keadaan masyarakat desa Leuwimekar, maka peran belum signifikan, faktor pendukung diantaranya kemajuan pesantren cukup pesat.

Pondok pesantren yang telah mengakar ditengah-tengah masyarakat, mempermudah komunikasi dengan masyarakat dalam sosialisasi programprogram pemberdayaan. Adanya dukungan pemerintah dapat meningkatkan keberhasilan program pemberdayaan oleh kelompok masyarakat lain.

Faktor penghambat diantaranya belum tersedianya bagian atau divisi khusus pemberdayaan masyarakat. Terbatasnya sumberdaya manusia dan finalsial, sehingga program pemberdayaan baru dapat dilaksanakan kepada masyarakat di luar pesantren. Masih rendah ditingkat pendidikan warga sekitar, menjadikan pemahaman makna pemberdayaan lambat untuk diterima.

Mental "tangan di bawah" masih tampak kuat di masyarakat. Kerja sama antara pemerintah daerah, pondok pesantren, warga dalam menggali potensi pemberdayaan masyarakat perlu ditingkatkan.

\section{Implikasi}

Berangkat dari kesimpulan, peneliti perlu membuat rekomendasi yang disampaikan kepada:

a. Pemerintah, khususnya pemerintah daerah untuk memperkuat pelaksanaan kemitraan dalam mengentaskan kemiskinan. Pondok pesantren adalah 
mitra strategis yang harus digandeng menggali potensi masyarakat.

b. Pihak Pesantren, agar lebih mendalami tujuan pemberdayaan masyarakat menurut konsep pemberdayaan masyarakat dan adanya badan atau bagian pemberdayaan masyarakat.

c. Umum, diharapkan dapat melakukan penelitian lebih mendalam dengan obyek yang berbeda, lebih menggali informasi pada orang-orang/lembaga yang terkait dengan pemberdayaan masyarakat.

\section{DAFTAR PUSTAKA}

Arifin Z. 2012. Evaluasi pembelajaran. Remaja Rosdakarya, Bandung.

Damsir I. 2016. Pengantar sosiologi pedesaan. Kencana, Jakarta.
Departemen Agama. 2001. Pola manajemen penyelenggaraan pondok pesantren. Direktorat Jendral Departemen Agama RI, Jakarta.

Latif A. 1993. Membangun SDM yang mandiri dan profesional. Departemen Tenaga Kerja RI, Jakarta.

Siradj SA. 2014. Kata pengantar kumpulan bahan ajar. Rumah Kitab, Jakarta.

Soebahar AH. 2013. Modernisasi pesantren. LkiS Printing Cemerlang, Bantul.

Sugiyono. 2016. Metode penelitian kuantitatif, kualitatif, dan R\&D. Alfabeta, Bandung.

Sulaiman I. 2010. Masa depan pesantren. Madani, Malang.

Suyono H dan R Haryanto. 2009. Pedoman pembentukan dan pengembangan posdaya. Balai Pustaka, Jakarta.

Yusuf AM. 2014. Metodologi penelitian kuantitatif, kualitatif, dan penelitian gabungan. Prenadamedia Group, Jakarta. 